\title{
India's health ministry inspects airports for Ebola preparedness
}

\author{
Sanjeet Bagcchi
}

Kolkata

The Indian health minister, Jagat Prakash Nadda, has formed a committee with officials from the ministries of health, civil aviation, and immigration to check that all airports in the country are adhering to guidelines on quarantining people with suspected Ebola virus disease. The committee will report to the government in a week.

A statement from the government said that Nadda emphasised the importance of alertness, intensive training, and capacity building of all stakeholders to be better equipped to deal with Ebola. ${ }^{1}$

He asked health ministry officials to form expert teams that would visit Indian states and report on the preparedness of their designated hospitals. He said that the training of doctors and medical staff should be a continuous exercise.

Nadda said that India had a large medical force available within the defence ministry and that this force "could be beneficially utilised at the time of need." He added that capacity building for Ebola case management should be initiated for these doctors and nurses to equip them for the emergency response.

Nadda has also sought a detailed report on the surveillance measures for Ebola virus disease in Indian seaports.
On 18 November a 26 year old resident of India was quarantined at Delhi's Indira Gandhi International Airport. Although the man was said to be cured of the disease, his semen tested positive for the Ebola virus.

TIME magazine reported that the man had no symptoms of Ebola infection and tested negative for the virus before he flew from Liberia. ${ }^{2}$ It said that semen can test positive for up to three months after clinical clearance of the virus and that the man would be kept in the airport's health facility until his semen tested negative.

Access all of The BMSs content on the ongoing Ebola outbreak at thebmj.com/ebola.

1 Government of India. Sh J P Nadda chairs inter-ministerial review meeting on Ebola. 19 Nov 2014. http://pib.nic.in/newsite/PrintRelease.aspx?relid=111547.

2 Sifferlin A. India's first Ebola patient has been quarantined. TIME 2014 Nov 18. http://time. com/3592142/ebola-in-india/.

Cite this as: BMJ 2014;349:97328

๑) BMJ Publishing Group Ltd 2014 